\title{
Annual Summary
}

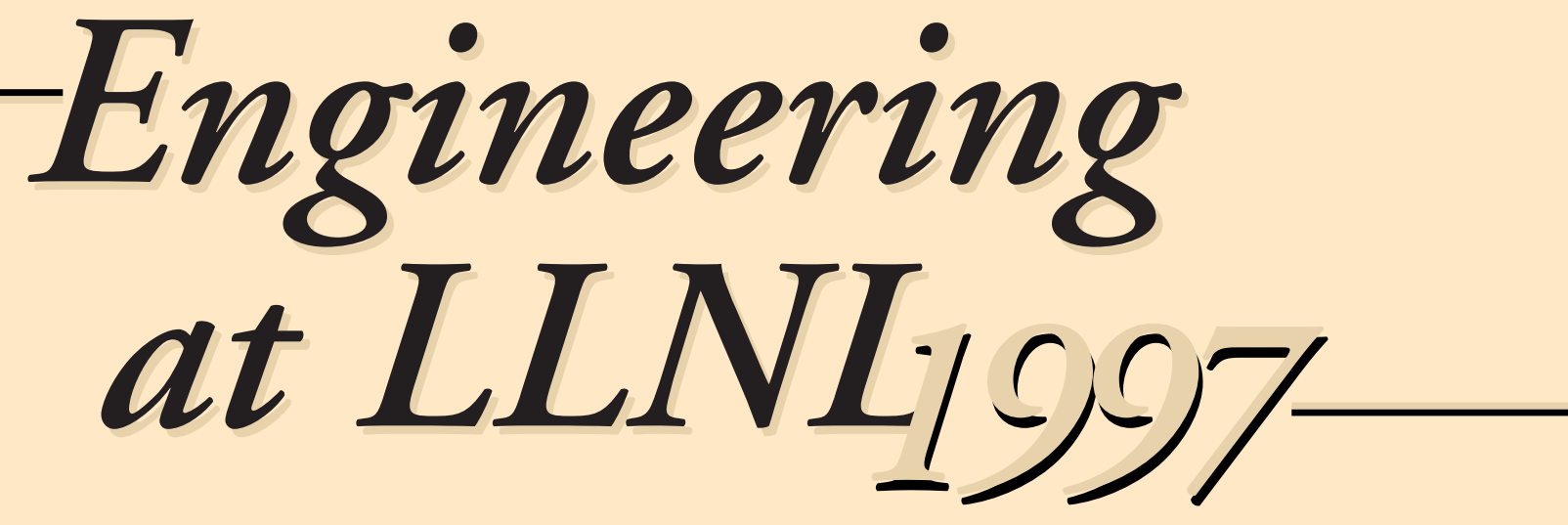

\section{《L}




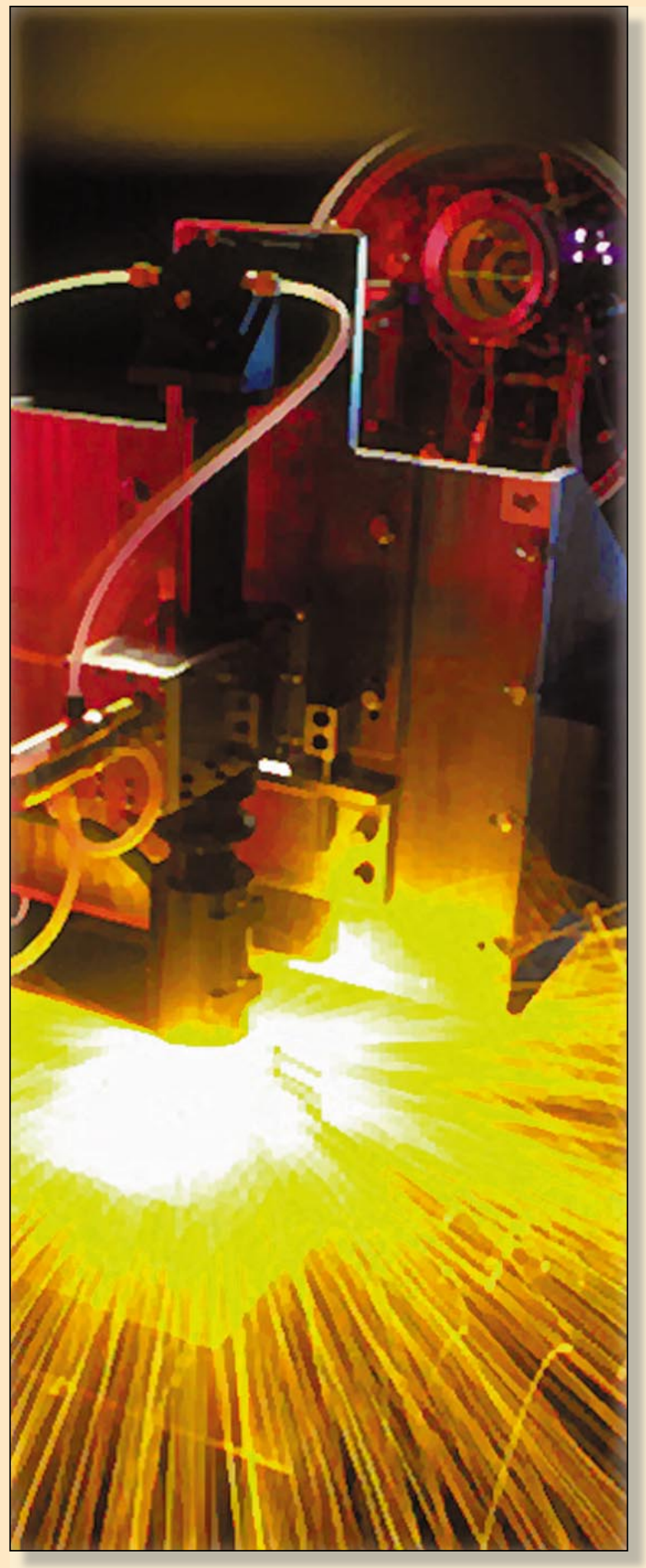

Livermore's program to refurbish the W87 warhead was a key Engineering activity in FY97. 


\section{Contents}

Associate Director's Message........................... 5

Overview of LLNL. . . . . . . . . . . . . . . . . . . . . . 7

LLNL Funding and Workforce. $\ldots \ldots \ldots \ldots \ldots \ldots \ldots \ldots \ldots$

Engineering Overview $\ldots \ldots \ldots \ldots \ldots \ldots \ldots \ldots \ldots \ldots \ldots, \ldots$

Mission...................................

Organization................................... 10

Engineering Facilities $\ldots \ldots \ldots \ldots \ldots \ldots \ldots \ldots \ldots \ldots \ldots \ldots \ldots \ldots, 10$

Engineering Funding and Workforce $\ldots \ldots \ldots \ldots \ldots \ldots \ldots \ldots \ldots \ldots$

Significant Accomplishments . . . . . . . . . . . . . . . . . 12

Business Accomplishments ...................... 12

Technical Accomplishments ....................... 14

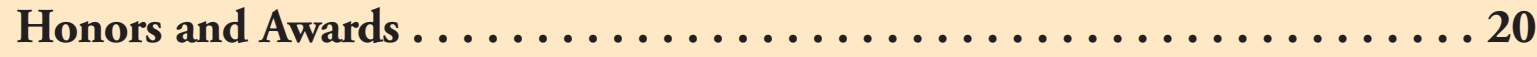

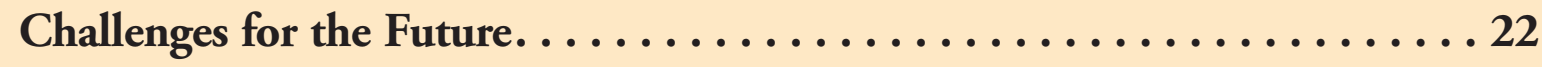

Appendices. .................................23 


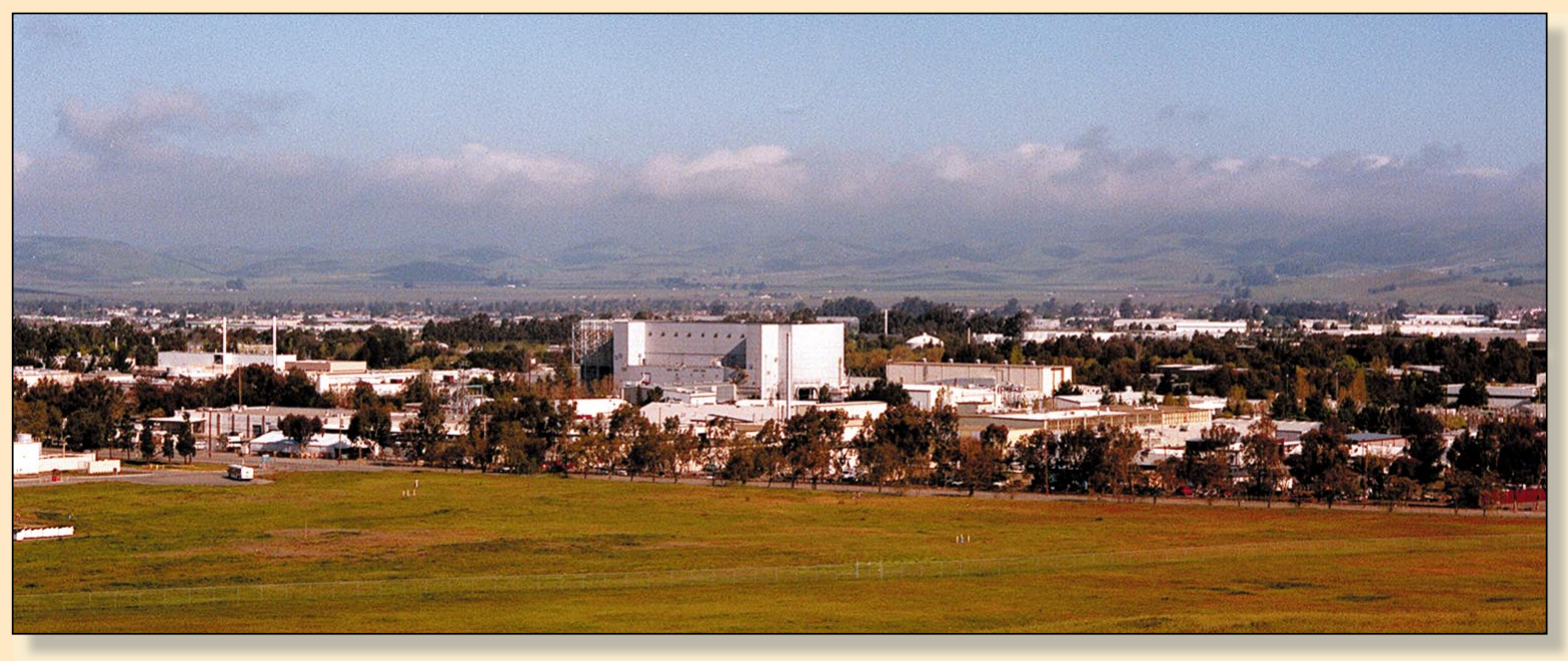

Engineering facilities are located throughout Lawrence Livermore National Laboratory.

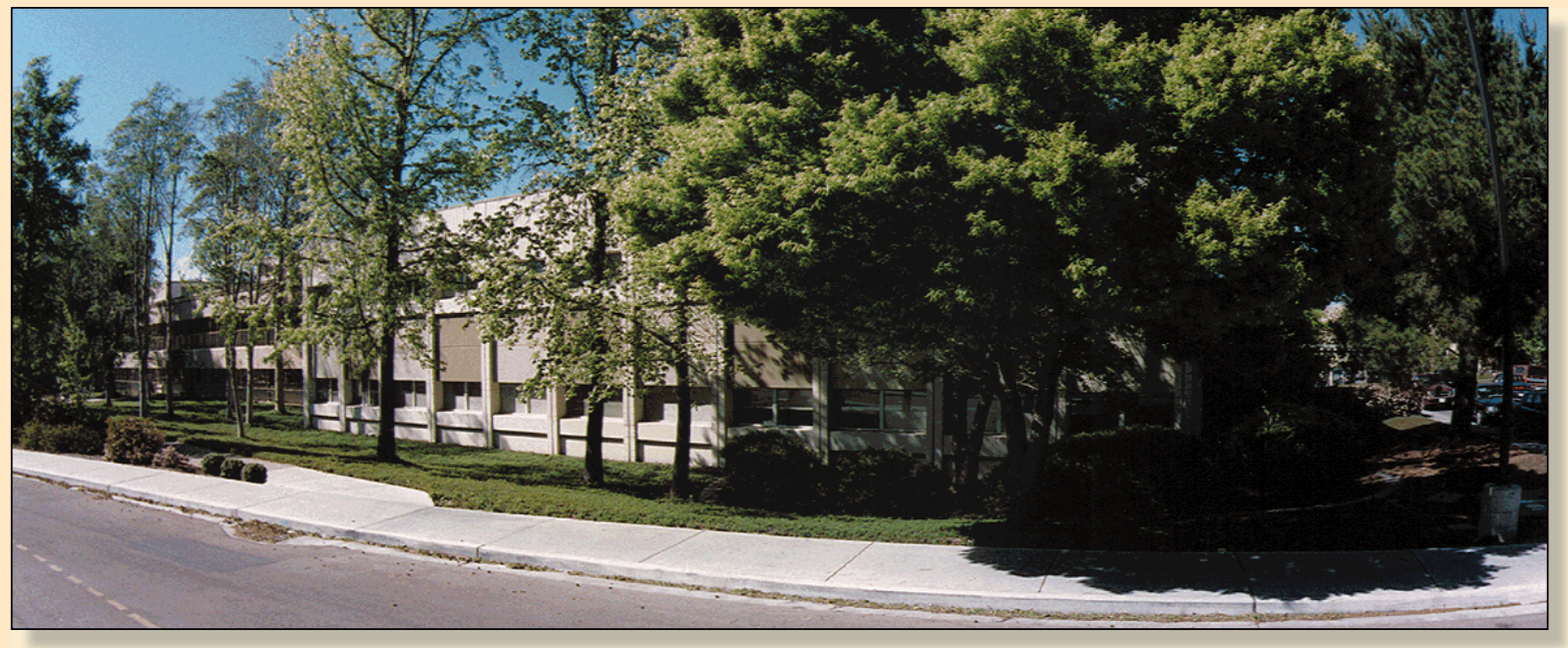

Building 131 is the main Engineering facility. 


\section{Associate Director’s Message}

Fiscal year 1997 has been another year of significant activity in Engineering marked by increased emphasis on meeting key Laboratory milestones, continued attention to further operational improvements, organizational readjustments, staffing, and progress in cost management.

In the programmatic area, strong growth in the National Ignition Facility (NIF) and Accelerated Strategic Computing Initiative (ASCI) programs allowed us an unparalleled opportunity to participate in the most challenging engineering $\mathrm{R} \& \mathrm{D}$ programs currently undertaken in the country and the opportunity to apply our computational engineering efforts to important Laboratory deliverables in the weapons area. In spite of our relatively short-staffed situation for much of the year, we managed to meet all critical milestones, including the more aggressive "capability stretching" goals requiring extraordinary innovation and dedication.

In the operations area, Mechanical Engineering undertook substantial re-assignments of senior management responsibilities, and Electronics Engineering consolidated from four to three divisions. Both of these adjustments were made in an effort to better align the Directorate with its evolving customer base, particularly in the Laser and Nonproliferation, Arms Control, and International Security areas.
In parallel, the Voluntary Separation Incentive Program (VSIP) was completed, and through that process, Engineering reduced its workforce in selected areas by approximately $7 \%$ of its total employee base. This reduction, coupled with significant funding growth, allowed Engineering to measurably and positively impact its skill mix while improving its operational leverage, or flexibility. Overall, a year following the completion of VSIP, Engineering's productivity was up by $5 \%$, while its flexibility had doubled; all this at a time where nationwide competition for engineering talent was at historic highs. In order to accomplish some of our staffing objectives, we had to establish innovative ways to augment our personnel, such as borrowing employees from downsizing U.S. Department of Energy (DOE) contractors, and thus contributing to the weapons complex's knowledge retention objectives.

Finally, Engineering costs were reduced for the fourth consecutive year, while the amount of funding directed toward competency development increased for the first time since recent cost reduction efforts began.

This report contains a detailed summary of our accomplishments. I hope you will find it both interesting and informative.
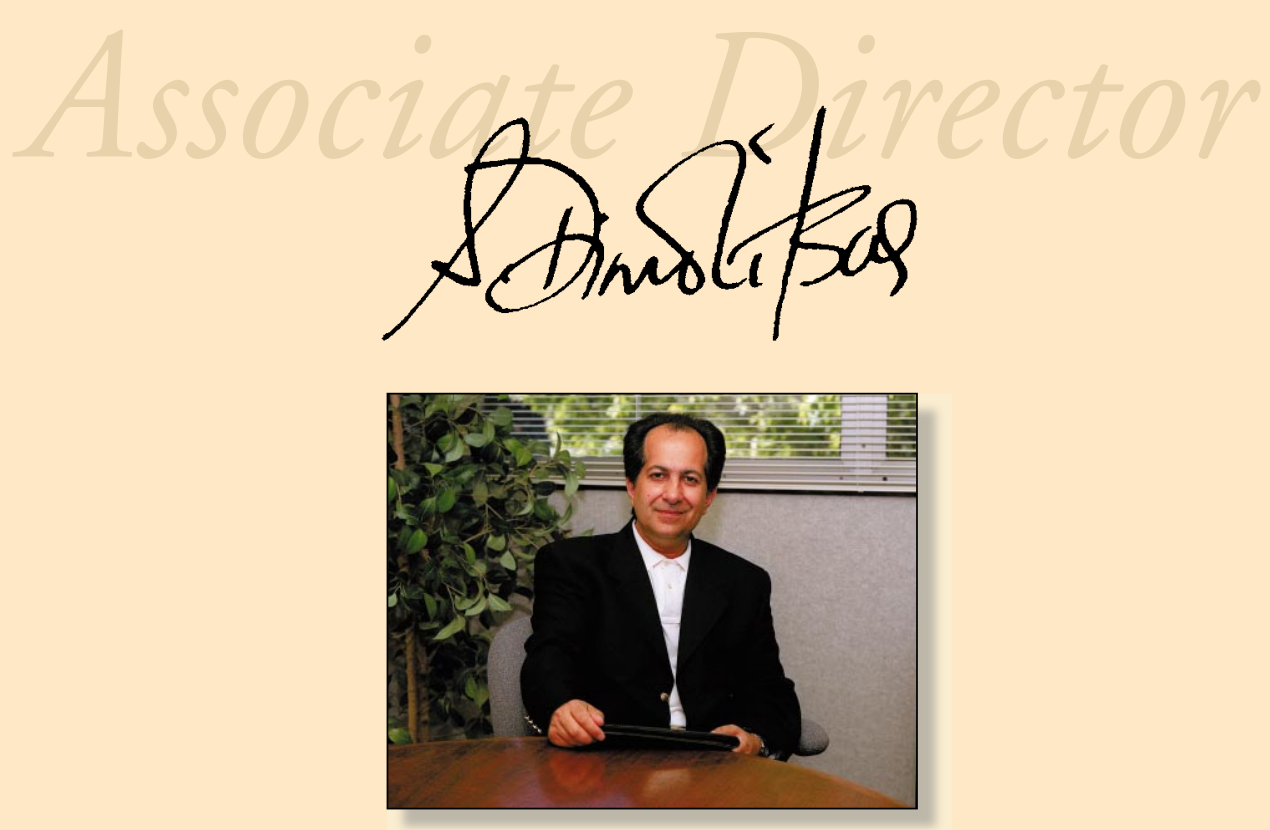


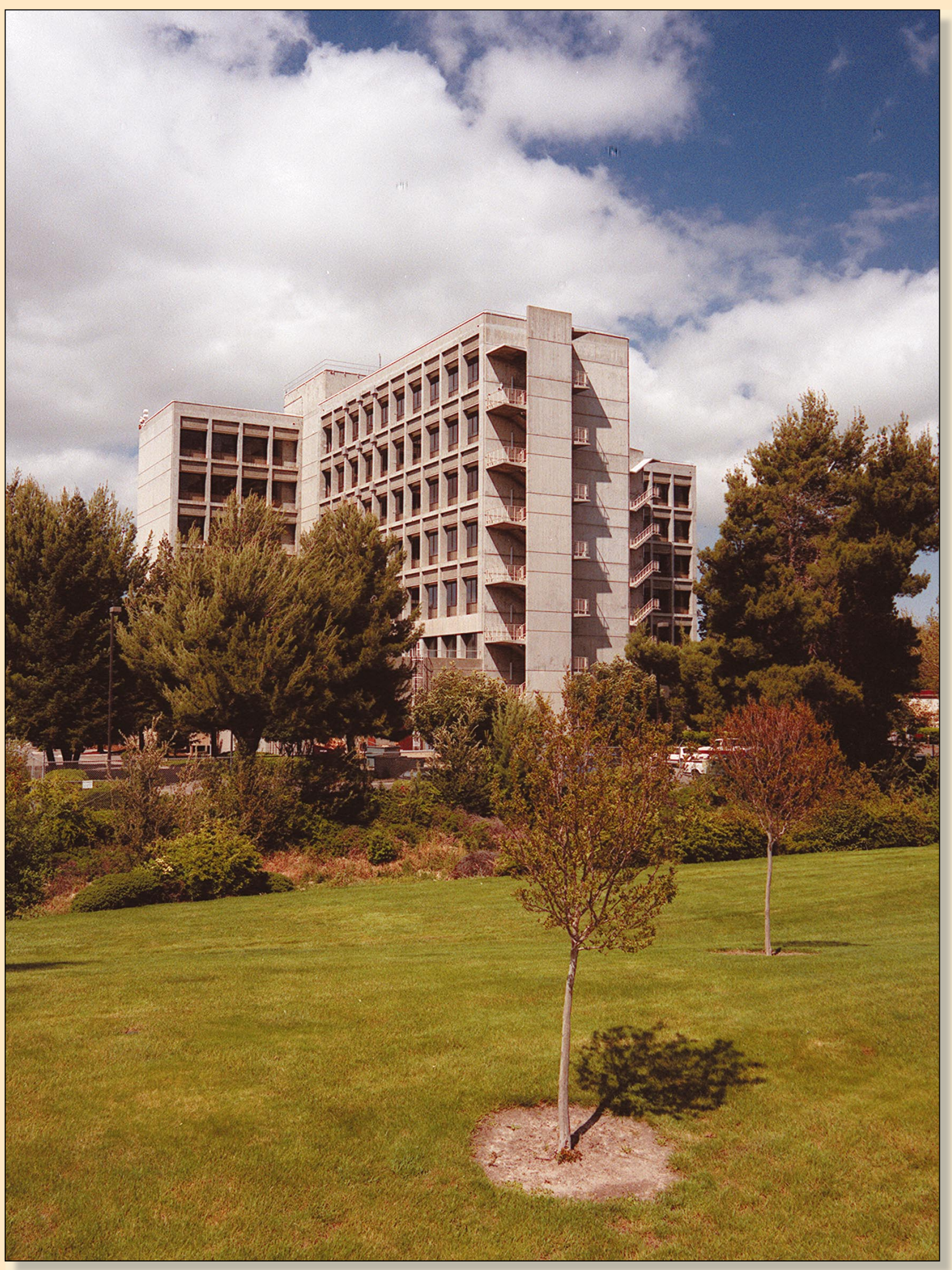




\section{Overview of LLNL}

Established in 1952, Lawrence Livermore National Laboratory (LLNL) is one of the world's premier applied-science national security laboratories. The primary mission of the Laboratory is to assure through the design, development, and stewardship of nuclear weapons, that the nation's stockpile remains safe, secure, and reliable and to prevent the spread and use of nuclear weapons worldwide.

National security is a principal integrating theme at LLNL — with stockpile stewardship, nonproliferation and arms control, and Department of Defense projects its major elements.

The Stockpile Stewardship Program, the primary Laboratory program, is a science-based versus testingbased approach to maintaining stockpile safety and reliability. The idea is to replace weapons development and nuclear testing with weapons life extension and intensive computational and experimental research to provide the fundamental understanding necessary to ensure nuclear weapons safety, performance, and maintenance.
Stockpile stewardship is enhanced and complimented by a second pillar of national security at the Laboratory: countering the spread of weapons of mass destruction. In the broad areas comprising nonproliferation, arms control, and international assessments, the growth of new technologies has been exponential at LLNL. Our ability to produce advanced microsensors-from scientific concept to working field model -is just one of the many contributions LLNL has made to the nation in counterproliferation against nuclear, biological, and chemical weapons.

In addition, LLNL's unique competencies developed in support of its national security mission have become an important resource for U.S. industry and government. Programs include advanced defense technologies, energy, environment, biosciences, and the basic sciences.

Central to the Laboratory's success is its diverse, highly talented, and skilled workforce and its $\$ 4$ billion capital invested in plant and research facilities. The University of California (UC) has managed the Laboratory since its inception, under contract with the DOE and its predecessors. 


\section{Funding and Workforce}

In FY97 the Laboratory's budget was flat at approximately the previous $\$ 1$ billion FY96 level. From this, $\$ 879$ million was devoted to operations, and $\$ 140$ million to capital investment projects. (See Figures 1 and 2.)

On average, LLNL's staffing level in FY97 consisted of 6,500 career employees (excluding summer hires and temporary employees) and 670 contract employees. (See the LLNL Staffing and Education Levels chart in the Appendix.) Scientists and engineers comprised $38 \%$ of the staffing mix, technical and crafts personnel $38 \%$, and administrative and clerical 24\%. Among the scientific staff, $37 \%$ were engineers, $30 \%$ were physicists. The remaining 33\% of the scientific staff was comprised of chemists, computer scientists, environmental scientists, metallurgists, and other categories. (See the Engineering Staffing Profile in the Appendix .)

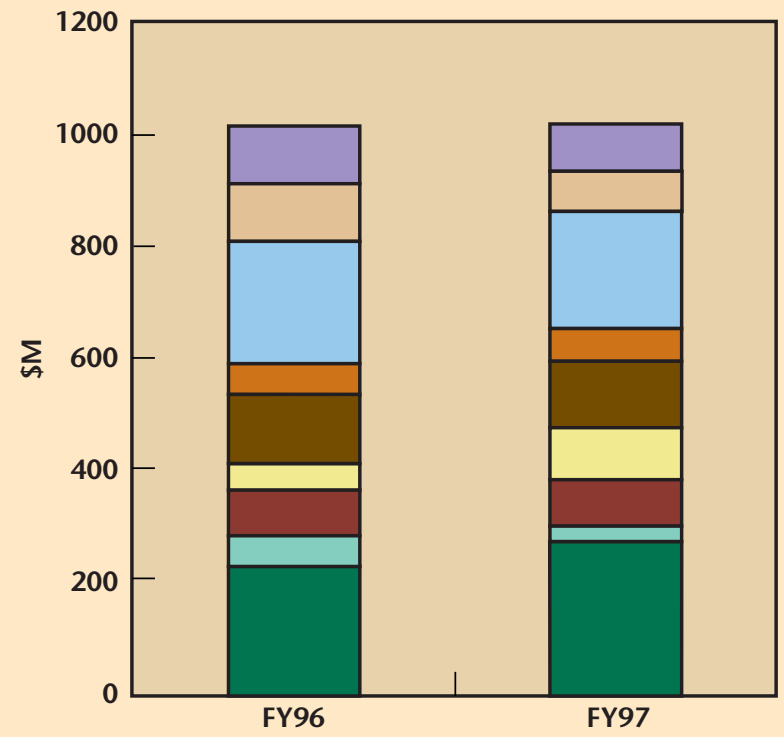

$\square$ Other

口 DOE Equipment/Construction

口 Non-DOE Customers

№n-Proliferation and Intelligence

- Energy, Environmental, and Biosciences

National Ignition Facility

- Inertial Confinement Fusion/Advanced Isotope Separation

口 Technology Transfer/Education

a Weapons

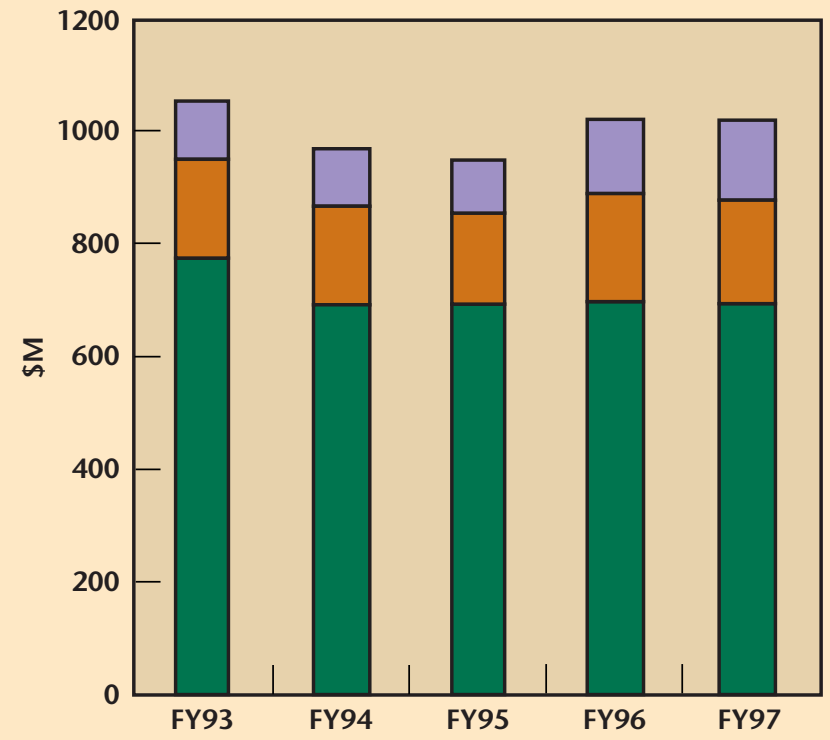

口 Capital Projects

口 Non-DOE Operating

口 DOE Operating 


\section{Engineering Overview}

\section{Mission}

Engineering's mission is to turn physics ideas into reality. This means that Engineering designs and builds most of the Laboratory's experimental projects, which are used to conduct physics and engineering research. Engineering also does the engineering design of many of the Laboratory's end deliverables, such as weapons where it has cradleto-grave responsibility. In addition, Engineering's mission is to conduct research in advanced engineering technologies so that new directions can be pursued by the Laboratory over time.

To fulfill its mission, Engineering provides the functional home for most of the engineering and technical talent working in the Laboratory, and as a consequence, Engineering hires virtually every engineer that works at LLNL. In addition, Engineering develops and maintains a significant number of facilities used for fabrication or to conduct engineering research. Finally, because
Engineering is the largest scientific and technical organization at the Laboratory, and because of the Laboratory's matrix system that induces people to be dynamic by moving between projects from time to time, Engineering performs an internal technology transfer function that contributes significantly to the Laboratory's creativity.

In support of the variety of research and development activities at LLNL, Engineering conducts innovative research and development in the following four core competencies: integrated engineering of large-scale, complex applied physics systems; large, complex computational modeling and simulation; microscale engineering; and measurement science at extreme dimensionalities. These competencies form the foundation for the vitality of Engineering's core technologies: integrated mechanical, electrical, and controls system design; computational engineering; precision engineering; microsystems technology; signal and digital image processing; and non-destructive characterization.

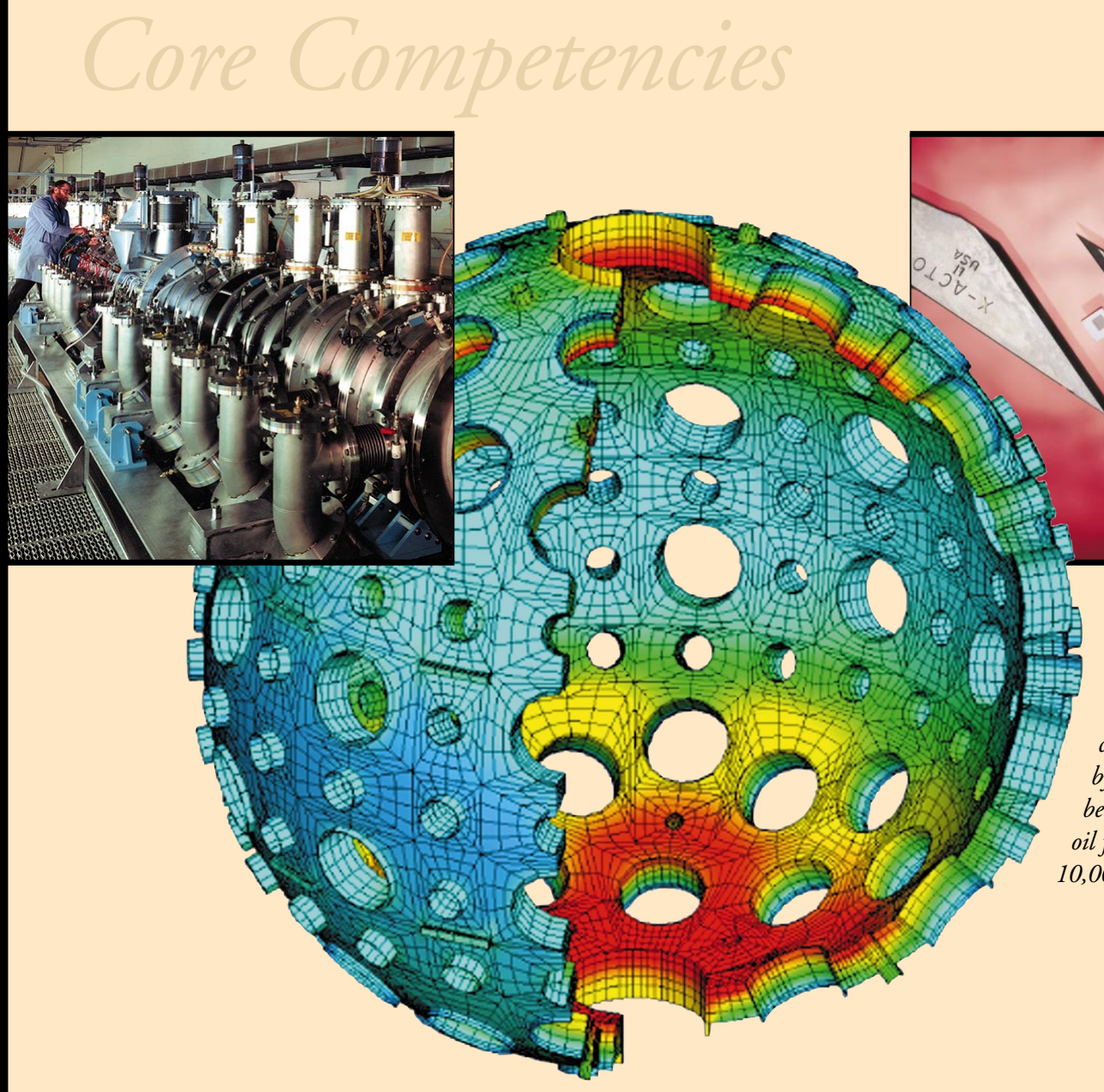

Shown from left to right are projects representative of Engineering research in the four core competency areas including the FXR upgrade project, the NIF target chamber modeled by LLNL'S NIKE3D and TOPAZ3D codes, the world's first fullerene waveguide array developed by Engineering's Microtechnology Center (photographed between two X-acto knife blades to indicate scale), and the oil field tiltmeter which can image hydrofractures at least 10,000 feet below the surface of a well. 


\section{Organization}

The Engineering Directorate is a multidisciplinary organization with expertise in most of the major engineering fields. In FY97, the Directorate was organized along two fundamental disciplines, mechanical and electronics engineering. (For further information refer to the Organization Chart in the Appendix.) Its wide-ranging capabilities are a direct outgrowth of Livermore's nuclear weapons work and the interdependence of weapons design, computational modeling, engineering, safety, and performance. The Directorate simulates engineering systems, improves systems designs, and tests performance when built. Engineering manages numerous large- and smallscale projects requiring complex interactions among many scientific disciplines. There are approximately 2,100 employees in Engineering, with approximately 1,800 typically assigned (matrixed) to work directly in support of other Laboratory organizations.

\section{Engineering Facilities}

Engineering owns and operates 30 facilities at the main LLNL site in Livermore. These facilities total 770,000 gross square feet, with $70 \%$ dedicated to working engineering laboratories, shops, and computer, equipment, and storage space, and 26\% dedicated to office space. In addition, Engineering operates 36 buildings and magazines at Site 300, a 45-square-mile test site that LLNL manages near Tracy, California. (See the Site Map in the Appendix.)

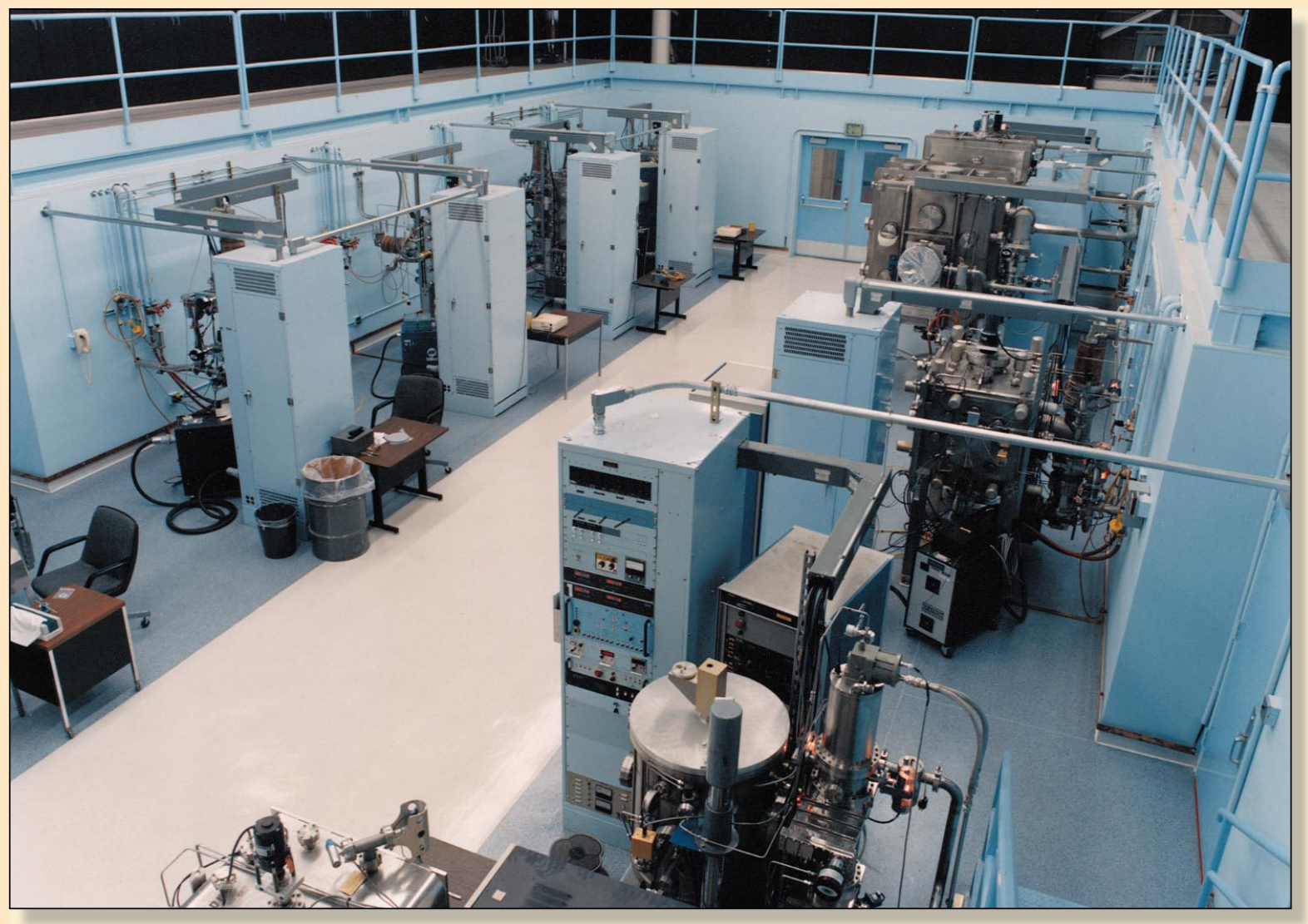

The Vacuum Process Facility pictured above allows parts as large as $100 \mathrm{~cm}$ in diameter to be coated or etched uniformly. The modular design of these systems permits complex coating designs to be fabricated using the optimal process for the application at hand. 


\section{Funding and Workforce}

\section{Funding}

Engineering's \$331.4 million FY97 funding came from three sources: programmatic support, distributed costs, and direct funding.

- Programmatic support is derived from LLNL programs. Engineering assigns approximately $80 \%$ of its personnel to work in the programs. In FY97, programmatic support accounted for approximately $\$ 270$ million, or $82 \%$ of Engineering's funding. The associated funding is managed within the programs, but pays for the salaries of Engineering's matrixed personnel.

- Distributed costs are associated with the following: Organizational Personnel Charges (OPC) to fund activities such as technology development, personnel management, administration, recruitment, conferences and training; Organization Facilities Charges (OFC); recharges from Engineering Service Centers such as Manufacturing and Materials Engineering, Electronics Manufacturing, and the Engineering Records Center; General and Administrative (G\&A) costs; and Program Management Costs (PMC). Distributed costs accounted for $\$ 54$ million, or $16 \%$ of Engineering's FY97 funding.

- Engineering's third funding source, direct funding, is for work done under contract for the DOE or other government or commercial customers. It also includes the Laboratory Directed Research and Development (LDRD) program. Direct funding accounted for $\$ 7$ million, or $2 \%$ of Engineering's FY97 funding.

\section{Workforce}

As LLNL's largest scientific organization, Engineering provides support to all Laboratory programs. In FY97, Engineering's full-time equivalent (FTE) workforce increased by $1.3 \%$. As a result of stockpile stewardship efforts, support to Defense and Nuclear Technologies showed the greatest increase from October of 1996 to September of 1997.

Figure 3. Engineering funding by budget type FY96-FY97 (excluding programmatic support).

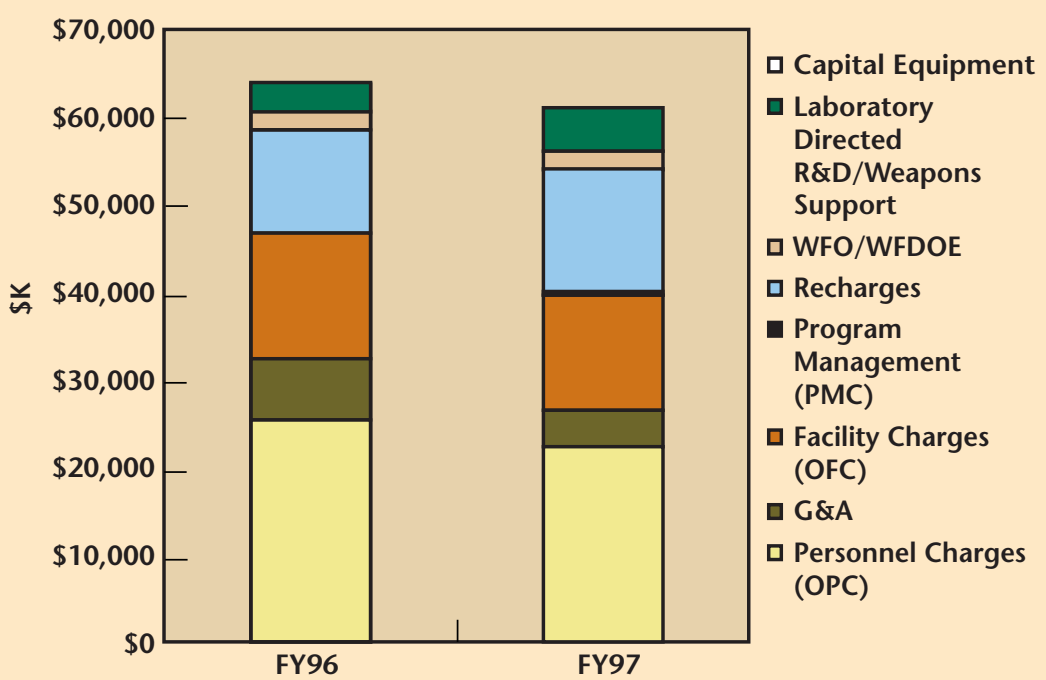

Figure 4. Engineering five-year funding trend (excluding programmatic support).

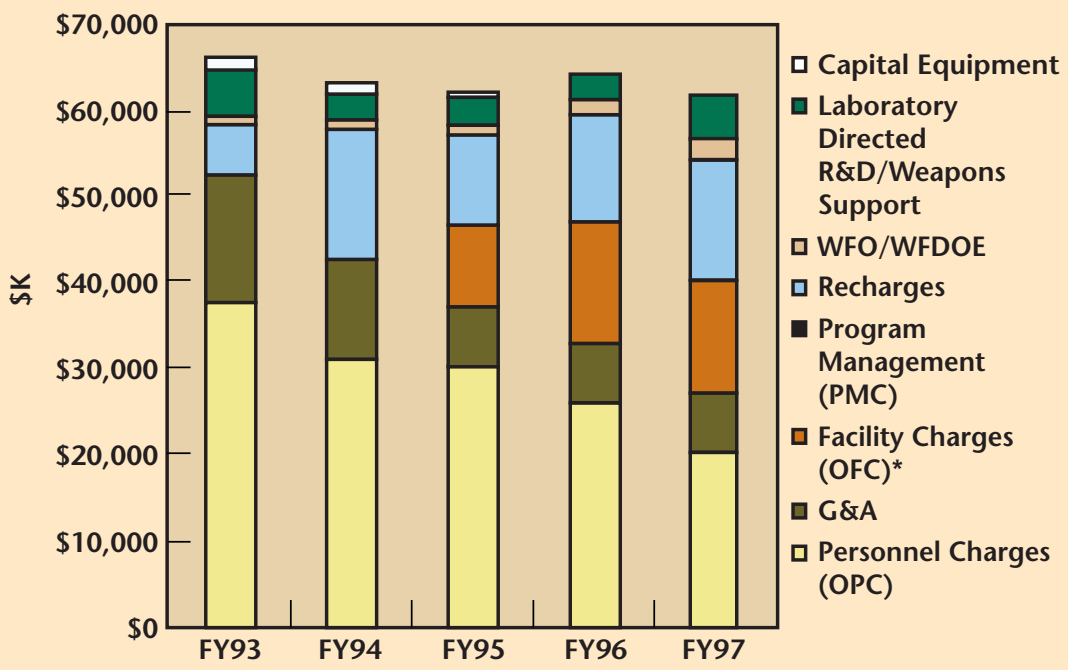

${ }^{*}$ FY96 \& FY97 reflect institutional costs (LFC) passed on to Engineering 
Second, Engineering devoted more efforts to further improving its cost structure and increasing the resources made available for core competency development. In FY97, Engineering's OPC was reduced to the lowest level (16.8\%) since the accounting restructuring was instituted in FY95 (when the rate was $23.3 \%$ ). This, combined with the Institution's six-point G\&A rate reduction, allowed the true cost of business to be reduced by 5\% from FY96, and 11\% from FY95.

In addition to overhead cost reductions, Engineering positioned itself to double the funding available for core competency development without increasing the cost to its customers. Entering FY98, this objective was largely achieved through a combination of organizational restructurings, divestment from facilities and investments no longer strongly coupled with the Laboratory's future, and by taking full advantage of the Laboratory's tailored VSIP activities.

In FY97, Engineering continued to make progress on the consolidation plan with the main thrust being the consolidation of Electronics Engineering and Mechanical Engineering fabrication capabilities in the Manufacturing \& Materials Engineering Complex (Building 321). This year the welding shop was reconfigured into a smaller space, the machine tool development labs were moved to building 432, and the waterjet cutting machine and the Certification of Process gage were moved to new locations in Building 321. Over
8,000 square feet of shop space was cleared out and refurbished. In addition, design began for converting 14,000 square feet into new offices and laboratories, and an 11,000 gross square feet office trailer complex (T3276), formerly occupied by the MMED staff was returned to the institution and subsequently demolished.

In line with its long-term facility consolidation and improvement plan, a $\$ 20 \mathrm{M}$ line-item for the Engineering Core Technology Center/321 Complex Upgrade was submitted to DOE/HQ, and approval obtained to prepare a conceptual design report for submittal to DOE in March 1998.

Engineering also successfully acquired $\$ 900 \mathrm{~K}$ in General Plant Projects funding to expand the Building 153 Microtechnology Center so that it can accommodate an increased volume of business across the Laboratory. This includes part of the newly formed \$250 million Extreme Ultraviolet Lithography Limited Liability Corporation venture which LLNL, Sandia National Laboratories, Lawrence Berkeley National Laboratory, TRW, Intel, Advanced Microdevices, and Motorola have jointly entered into.

Finally, Engineering translated its long-term goals set to one that is more broadly applicable to the type of work its employees do, and embarked on a process to incorporate these goals more directly into each employee's performance appraisal beginning in FY98. 


\section{Technical Accomplishments}

\section{Atomic Vapor Laser Isotope Separation (AVLIS) Separator and Laser Tests}

Beginning in July of 1995, the largest technology transfer in the history of the Laboratory began. Sponsorship of the entire AVLIS program was transferred to the U.S. Enrichment Corporation (USEC). The technology of laser isotope separation of uranium has been under development at the Laboratory for over 25 years. In the mid 1980's it was selected as the preferred technology for the enrichment of uranium for reactor fuel over competing gaseous centrifuge technology.

It is the intent of USEC to commercialize the process to supply its share of the world market for enriched uranium. Engineering is providing much of the engineering design and testing support for this program. It is a cost and schedule-driven program that is poised to become part of a private corporation when the sale of USEC is completed either by an initial public offering or purchase by another company or corporation.

For the process to be economically viable, it must be transitioned to a production plant. The program and program support personnel faced a daunting challenge last year. USEC needed to run the facility for more hours than it had totally run in the last ten years. We are happy to report that not only was this accomplished, but almost all of the objectives were achieved on each run. We successfully completed five runs in 1997 totaling more than 1,600 hours. Three of the runs exceeded the initial operating goal of a continuous 400-hour run. The final two runs ( $\mathrm{S}-12$ and S-13) combined the laser system with the separator system to demonstrate plant-like enrichment.

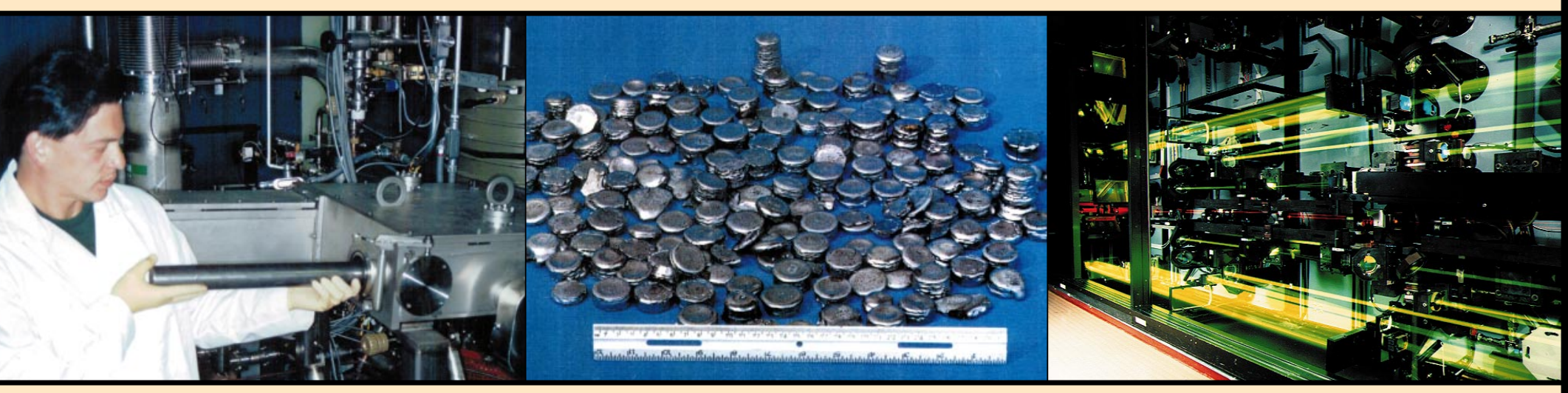

The AVLIS process enriches uranium alloy feedstock to a level needed to fuel nuclear power plants. Physically, the raw material is injected in the form of a bar (left) and emerges as nuggets (center) containing a higher level of U-235, the isotope that provides the fission energy. In an actual production scenario, the enriched nuggets produced by AVLIS would then be processed into fuel rods by commercial fuel fabricators. AVLIS incorporates heavy engineering with the latest in opto-electronics and distributed real-time control systems (right). 


\section{Zephyr}

Zephyr, a streamlined, paperless, procurement system, was named for the famous California streamliner. The Electronics Engineering Department, Administrative Information Systems, and Procurement developed a pilot implementation of this highly integrated engineering development cycle that cuts procurement times by as much as $90 \%$ as it reduces the cost of paper processing. The concept merges engineering and commerce via secure (i.e., encrypted and passwordprotected) transactions over the Internet. Small and medium-sized (SMEs) businesses are encouraged to prequalify for Zephyr transactions with LLNL. Typically, soon after engineering design release, a buyer issues an electronic request for quote package on an encrypted Zephyr home page (http://zephyr.llnl.gov/). Then, again electronically, Zephyr takes care of the announcement, solicitations for bid-quote, award, technical data exchange, payment, delivery tracking, and the record-keeping and audit trail requirements. The system also assists engineers to rapidly prototype designs and efficiently find collaborators via the Internet, further helping to compress project schedules for large programs such as the National Ignition Facility.
Zephyr - the concept is called Engineering and Commerce on the Internet (ECI) - received a Best Practices Award from the DOE and the DoD, and was one of the DOE initiatives for the Advanced Manufacturing National Information Infrastructure to help advance American manufacturing. Zephyr will link Engineering not only to the Procurement and Finance organizations at LLNL, and be adopted for Lab-wide procurements, but will also be employed on both a national and international scale. It was linked to the Commerce at Light Speed (CALS) Working Group, U.S. Department of Commerce, of which LLNL is a member, and ultimately will help bring about the Internet-based electronic marketplace. Presently, the University of California's Haas School of Business, Fisher Center for Business and Management, is finishing a Zephyr Case Study detailing the development of LLNL's unique engineering capability.

\section{NIF Title I Review Completed}

The National Ignition Facility (NIF) is being built as a major element of the DOE's Stockpile Stewardship Program to preserve confidence in the safety and reliability of the U.S. nuclear weapons and to preserve core nuclear weapons competencies in the absence of nuclear testing. It will be the world's largest laser and has an estimated cost of $\$ 1.2$ billion. It will be the size of a modern sports stadium and is the largest construction project and permanent facility in the Laboratory's history. It will combine 192 separate laser beams that are designed to be fired simultaneously and focus on a target capsule 1-to-3 millimeters in diameter containing deuterium-tritium fuel. The beams will precisely compress and heat this target to 100 million degrees.

This year we completed $100 \%$ of the conceptual design phase (Title I) of the project. 


\section{PEP II High-Energy Ring}

The PEP II (Positron-Electron Project) High Energy Ring is one of the two charged-particle storage rings at the B-Factory, an enormous accelerator facility scheduled for completion in 1999 by a consortium between Stanford, LLNL, and Lawrence Berkeley National Laboratory. This BFactory, located at the Stanford Linear Accelerator Center (SLAC), and another in Japan, will generate millions of $\mathrm{B}$ mesons and anti-B mesons through the collision of electrons and positrons moving at near the speed of light. A key feature of this collider is that electrons and positrons will circulate and collide with unequal (or asymmetric) energies so scientists can better study the particles generated in the collisions. Scientists from over 75 institutions world-wide, including LLNL, will use these particles to study charge-parity violationthe small differences in the way that certain shortlived particles and their antiparticles decay.

Charge-parity violation is thought to be the reason that the universe seems to be composed almost exclusively of matter. Finding out why the universe contains essentially no antimatter is a necessary step in understanding the fundamental nature of matter and energy.

In addition to previous and ongoing LLNL engineering and manufacturing work on other components of the B-Factory, in 1997 the Accelerator Technologies Engineering Group (ATEG) contributed to the design and fabrication of several key PEP II accelerator components, including vacuum systems, magnets, radio-frequency oscillator cavities, and beam dumps. The PEP II High Energy Ring, an underground ring $2.2 \mathrm{~km}$ in diameter at SLAC, was operated for the first time with 9-GeV electrons on June 3, 1997. By June 26, the stored lifetime of the beam was increased to more than 3 hours and reached a 50-milliamp $(\mathrm{mA})$ beam current. This three-year project cost $\$ 170$ million and was successfully completed on time, meeting a major DOE milestone.

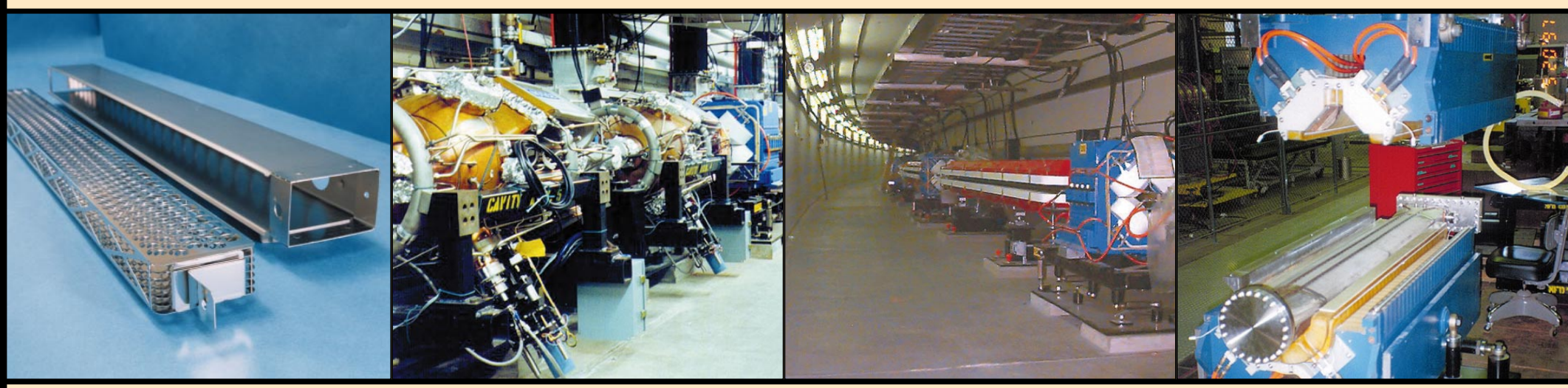

LLNL Engineering made a number of significant contributions to the PEP-II High Energy Ring (HER). From left to right, ATEG developed, designed, built and tested the distributed ion pumps for the HER arc sections; MMED fabricated and assembled the $26 \mathrm{rf}$ cavities for the project; ATEG designed the vacuum chambers for the HER straight sections; and ATEG designed the septum quadrupole magnets and vacuum chambers for the HER interaction region. 


\section{High-Resolution Computed Tomography of a Weapons Pit}

Engineering teamed with imaging scientists from the Laser Directorate to produce the first 3-D x-ray images of a nuclear weapons pit. This was done for the Enhanced Surveillance Program. This imaging system employs 9-MV Bremsstrahlung radiation. The pit computer tomography data set has produced a full 3-D pit image that reveals internal features that cannot be seen by any other nondestructive method. It employs a volume radiograph imaging system that produces a point spread function with a full width half maximum of $100 \mu \mathrm{m}$. This results in a resolved volume 3-to-10 times smaller than previously achieved. This is a very significant development for the Stockpile Stewardship Program.

\section{Tiltmeter}

This new device, honored with an R\&D 100 Award, is used in oil field production. Tiltmeters are sensitive instruments able to measure atomicscale changes in the tilt of the earth's surface. Although tiltmeters have been used in oil fields for years, they have lacked the sensitivity to measure the tiny surface tilts from deep wells, which are very expensive to drill.
Oil companies pump water under high pressure into their wells to create cracks in the oil-containing rock layers which increases production. The water pressure causes a tiny bulge in the earth's surface. Although this bulge is about a mile in diameter for a well two miles deep, it is only about onemillionth of an inch high. The new tiltmeter measures the infinitesimal tilt caused by this bulge.

\section{Ultra-High Gradient Insulator}

The new ultra-high gradient insulator (UHGI) has also been honored with an R\&D 100 Award. Researchers from LLNL and Allied Signal, Kansas City have pioneered the new insulator. The motivation for this work was to improve key elements in nuclear weapons systems. The device sustains about four times the electrical voltage of similarly sized conventional insulators. Use of the new insulator can shrink these devices to one-fourth their current size. The fundamental advance of the UHGI device is that it uses extremely thin layers of alternating conducting and insulating material to sustain electrical voltage. It also offers a reliability advantage over current insulators. Once a conventional insulator breaks down, it will not run again at the same operating voltage. In contrast, the UHGI insulator can be ramped-up or reconditioned to its original operating voltage.

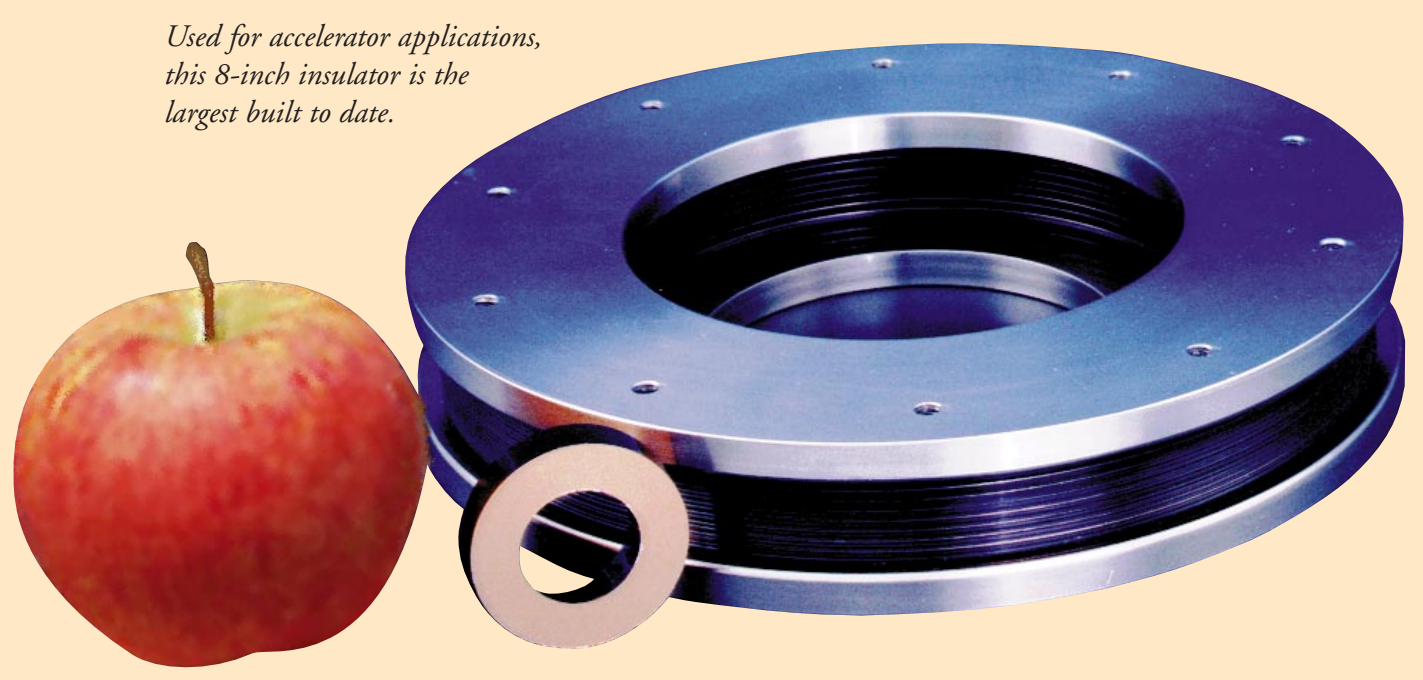




\section{Multiscale ElectroDynamics}

This system was also selected for an R\&D 100 Award last year. It is a computer code that runs on workstations and allows the user to construct a "virtual" optical bench. It can handle scale lengths that vary by $10^{6}$ and reduces the development cycle time and engineering costs by as much as $80 \%$. It is being used for the development of micro-optic devices used in new high-speed computers and communications systems.

It allows designers to quickly and accurately explore new photonics design and packaging approaches by eliminating the tedious trial and error fabrication, test, and development cycle. It has already been used by an industrial collaborator to speed up the design and implementation of an optical communication systems.

\section{Dugway Joint Field Trials}

In the aftermath of Desert Storm and Hussein's threat of the use of biological warfare (BW) agents, a team was assembled with the mission to develop defenses against these weapons. Along with members of the Nonproliferation, Arms Control, and International Security Directorate and the Biology and Biotechnology Research Program, Engineering was invited to participate in the Joint Field Trials III at Dugway Proving Groups in Utah. The JFT III field trials were the first trials at which realistic sample concentrations were used.

We were able to build upon two world-leading proprietary technologies, the flow-stream-waveguide flow cytometer, and the silicon-sleeve-based polymerase chain reaction (PCR) instruments to make small, portable instruments, "miniFlo" and "mini-PCR," respectively. The former was used for antibody-based assays, and the latter was used for nucleic-acid-based assays. Using the miniFlo we achieved $100 \%$ detection of all concentrations of B.g., the anthrax simulant, with $0 \%$ false positives for blanks and only $1 \%$ false positives due to cross reactivity of the antibody reagents. No other technique has ever shown a perfect score for true positives and no false positives for blanks.

(Left) Photo of miniFlo, the ID-capable cytometer that performed detection and quantification of unknowns at Dugway JFT III. (Center) The world's first fully automated PCR system used at the DoD "portal shield" field trial. (Right) Emergency response person using mock-up of PCR biodetector.
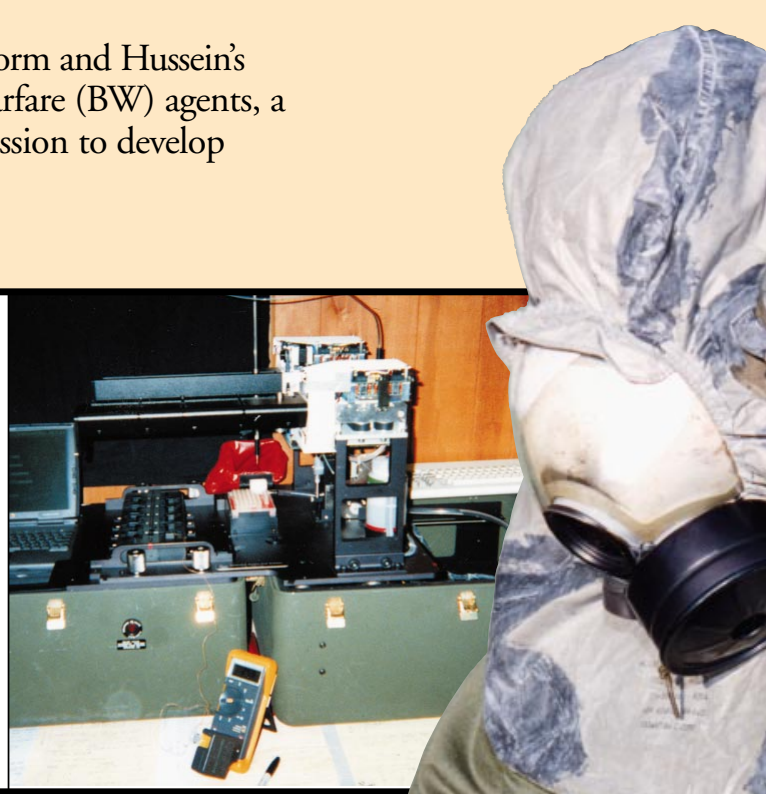


\section{Honors and Awards}

\section{R\&D 100 Awards}

Each year R\&D Magazine selects the 100 most technologically significant products and processes submitted for consideration and honors them with an R\&D 100 Award. Winners are chosen by the editors of the magazine and a panel of 75 experts in a variety of disciplines. Corporations, government laboratories, private research institutes, and universities throughout the world vie for this "Oscar" of applied research. The R\&D 100 judges look for products or processes that promise to change people's lives by significantly improving the environment, health care, or security. In FY97, the following Engineering employees won awards:

Frank Snell—Absolute Interferometer

Steve Herman-Femtosecond Laser Materials Processing

Steve Sampayan, Dave Trimble, Bob Stoddard and Dave Sanders-Ultra-High Gradient Insulator

Richard Ratowsky, Jeffrey Kallman, Robert Deri, and Michael Pocha-Multiscale ElectroDynamics (MELD)

Steven Hunter-Oil Field Tiltmeter

\section{LLNL Director's}

\section{Performance Awards}

Sally Bahowick-Portable Treatment Units

George Metzger-Portable Treatment Units

Maurice Hernandez-Portable Treatment Units

Fred Holdener-B-Factory Project at SLAC

Leonard Silva-AVLIS Dye Laser Facility Expansion

Samuel Rodriguez-NIF Title I and II

Design Packages
Anthony Gonzales-NIF Title I and II

Design Packages

Michael McDaniel—NIF Title I and II Design Packages

Wayne Whistler-NIF Title I and II Design Packages

Kenderick Wong-NIF Title I and II Design

Packages

Rudy Cavitt-NIF Title I and II

Design Packages

Steve Benson-Laser Cutting Project

Robert Cross—Laser Cutting Project

Donald Frank-Laser Cutting Project

Bradley Golick-Laser Cutting Project

Jeff Klingmann—Laser Cutting Project

Mark LaChapell—Laser Cutting Project

Richard Lanza-Laser Cutting Project

Keith Peterman-Laser Cutting Project

Douglas Sweeney_Laser Cutting Project

Steven Telford-Laser Cutting Project

Graham Thomas-Laser Cutting Project

Frank Snell—EUVL Milestone Technology Team

Don Masquelier-Mini-flow Cytometer

Steve B. Brown-Joint Field Trials III

at Dugway, Utah

Dean Hadley-Joint Field Trials III

at Dugway, Utah

Raymond Mariella_Joint Field Trials III

at Dugway, Utah 
James Richards_-Joint Field Trials III

at Dugway, Utah

Paul Stratton-Joint Field Trials III

at Dugway, Utah

Don Masquelier-Joint Field Trials III at Dugway, Utah

\section{Other Awards}

Zephyr Project—DOE Best Practice

David Gutierrez-NPR Hammer Award

Glenn Meyer-Award for Excellence in

Technology Transfer

Dino Ciarlo-Award for Excellence in Technology Transfer

Dennis Chakedis_DOE Appreciation Award (EEO \& Diversity Conference)

Roberto Ruiz-Spiral Track Autonomous Robot (STAR). Finalist in Discover Magazine Awards for Technological Innovation

Del Eckles-Spiral Track Autonomous Robot (STAR). Finalist in Discover Magazine Awards for Technological Innovation
Erna Grasz-Spiral Track Autonomous Robot (STAR). Finalist in Discover Magazine Awards for Technological Innovation

Mark Perez-Spiral Track Autonomous Robot (STAR). Finalist in Discover Magazine Awards for Technological Innovation

Greg Tietbohl, Petawatt Project-Best of What's New Award 1996-Popular Science Magazine

Maynard Holliday-the Former Soviet Union Meritorious Service Award

Don Lesuer-Elected Fellow of the American Society of Materials

Shin-Yee Lu-3-D Imaging-Discover Magazine Finalists

Bob Addis-Alumnus of the Year at Cal Poly, San Luis Obispo

Karla Hagan-Senior Member of The Institute of Electrical and Electronics Engineers, Inc.

Debra Krulewich-U.S. Department of Energy Integrated Manufacturing Predoctoral Fellowship for 1997-1999 


\section{Challenges for the Future}

In the coming year, our key challenges are:

- To continue to deliver on all program milestones, including the Laboratory's stretch commitments.

- To begin building a national reputation for Engineering and to appropriately relate this across the variety of work we do. Building our reputation is necessary to allow LLNL to take full advantage of our workforce's intellectual capacity and to make it possible for the Engineering Directorate to continue to attract and retain truly exceptional people.

- To implement our new technology plan (transitioning our nine Thrust Areas to five Centers), and, in each of our core technologies, to lay the foundation for replicating the success characteristics of DYNA—a breakthrough, unique innovation that put Engineering on the national map, and that broadly and significantly impacted Laboratory programs.

- To further improve our flexibility so that we can position ourselves to seamlessly respond to the eventual ramp-down of major Laboratory projects, and to attain and sustain a wisely invested, healthy level of capital and core competency investment.

- To strengthen our leadership team and help the Laboratory capture the next multihundred million dollar program.

- To improve our safety record. 


\section{Appendices}

LLNL Costs by Major Program (\$M) FY96-FY97 . . . . . . . . . . 24

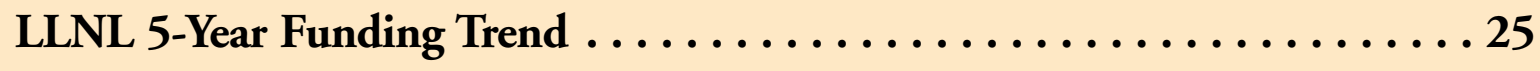

LLNL Staffing \& Education Levels-9/30/97. . . . . . . . . . . . 26

Engineering Costs by Budget Type FY96-FY97 . . . . . . . . . . . 27

Engineering 5 -Year Costs . . . . . . . . . . . . . . . . . . 27

Engineering Staffing Profile-9/30/97 ................... 27

FY97 Manpower Changes (FTEs) . . . . . . . . . . . . . . . 28

Engineering Workforce Changes-9/30/97. . . . . . . . . . . . . . 28

Engineering Senior Management-9/30/97 . . . . . . . . . . . . . 29

Engineering Facility Changes-9/30/97 . . . . . . . . . . . . . . 30 


\section{Appendices}

LLNL Costs by Major Program (\$M) FY96-FY97

\begin{tabular}{|c|c|c|c|}
\hline & FY96 & FY97 & \\
\hline Weapons & 230.8 & 269.7 & \\
\hline Technology Transfer/Educ. & 51.2 & 20.8 & \\
\hline Inertial Confinement Fusion/Adv. Isotope Separation & 84.3 & 84.8 & \\
\hline National Ignition Facility & 48.1 & 96.8 & \\
\hline Energy, Environmental, and Biosciences & 126.9 & 119.5 & \\
\hline Nonproliferation \& Intelligence & 56.0 & 60.3 & \\
\hline Non-DOE Customers & 217.1 & 212.3 & \\
\hline DOE Equipment/Const. & 100.3 & 72.1 & \\
\hline \multirow[t]{3}{*}{ Other } & 101.9 & 82.6 & \\
\hline & 1016.6 & 1018.9 & \\
\hline & FY96 & FY97 & $\begin{array}{c}\text { FY98 Plan } \\
9 / 30 / 97\end{array}$ \\
\hline DP01-CORE Stockpile Stewardship & 203.4 & 241.2 & 260.8 \\
\hline DP04-Stockpile Mgmt. & 27.4 & 28.5 & 38.3 \\
\hline Technology Transfer/Educ. & 51.2 & 20.8 & 7.8 \\
\hline ICF & 83.7 & 84.5 & 89.0 \\
\hline NIF & 16.9 & 29.3 & 50.0 \\
\hline GA-Fissile Matl. Disposition & 8.9 & 15.2 & 18.0 \\
\hline Nonproliferation \& Intelligence & 56.0 & 60.3 & 70.5 \\
\hline Env. Rest. \& Waste Mgmt. & 57.3 & 51.4 & 48.0 \\
\hline Other Defense & 22.8 & 20.0 & 14.9 \\
\hline Adv. Isotope Separation & 0.6 & 0.3 & 0.0 \\
\hline Magnetic Fusion & 11.0 & 9.8 & 10.6 \\
\hline NERSC & 14.4 & 0.0 & 0.0 \\
\hline Biomedical \& Environmental & 23.0 & 22.3 & 22.9 \\
\hline Basic Energy Science & 9.5 & 8.6 & 8.8 \\
\hline Energy Research & 17.2 & 12.1 & 16.4 \\
\hline SUBTOTAL DOE DIRECT OPERATING & 603.3 & 604.4 & 656.0 \\
\hline \multicolumn{4}{|l|}{ WFDOE: } \\
\hline NIF & 0.3 & 0.0 & 0.0 \\
\hline Pantex & 6.8 & 2.6 & 1.0 \\
\hline TPX-Princeton & -0.5 & 0.0 & 0.0 \\
\hline TRW-Waste Management & 14.7 & 16.7 & 17.0 \\
\hline Other WFDOE & 66.2 & 63.2 & 56.9 \\
\hline SUBTOTAL WFDOE & 87.5 & 82.6 & 74.9 \\
\hline TOTAL DOE OPERATING & 690.8 & 687.0 & 730.9 \\
\hline
\end{tabular}


LLNL Costs by Major Program (\$M) FY96-FY97 (continued)

\begin{tabular}{lrrr}
\hline & FY96 & FY97 & $\begin{array}{c}\text { FY98 Plan } \\
\mathbf{9 / 3 0 / 9 7}\end{array}$ \\
& & & \\
Non-DOE: & & & 3 \\
CEA-France & 11.9 & 6.6 & 73 \\
U-AVLIS (USEC) & 82.7 & 75.7 & 134.6 \\
Other NON-DOE & 99.7 & 110.0 & $\mathbf{2 1 0 . 6}$ \\
SUBTOTAL Non-DOE & $\mathbf{1 9 4 . 3}$ & $\mathbf{1 9 2 . 3}$ & $\mathbf{9 4 1 . 5}$ \\
SUBTOTAL OPERATING & $\mathbf{8 8 5 . 1}$ & $\mathbf{8 7 9 . 3}$ & 20.7 \\
\hline DOE Equipment & & & 4.9 \\
DOE GPP & 38.6 & 29.4 & 37.5 \\
DOE Line Item Construction & 5.6 & 6.0 & $\mathbf{1 4 0 . 7}$ \\
NIF Capital & 56.1 & 36.6 & $\mathbf{1 1 4 5 . 3}$ \\
& 31.2 & 67.5 &
\end{tabular}

\section{LLNL 5-Year Funding Trend}

\begin{tabular}{lrrrrr}
\hline & FY93 & FY94 & FY95 & FY96 & \multicolumn{1}{c}{ FY97 } \\
\hline DOE Operating & 775.3 & 693.2 & 689.4 & 690.8 & \multicolumn{1}{c}{687} \\
Non-DOE Operating & 176.5 & 164.8 & 163.7 & 194.3 & 192.3 \\
Capital Projects & 97.2 & 107.2 & 91.9 & 131.4 & 139.5 \\
& $\mathbf{1 0 4 9 . 0}$ & $\mathbf{9 6 5 . 2}$ & $\mathbf{9 4 5 . 0}$ & $\mathbf{1 0 1 6 . 5}$ & $\mathbf{1 0 1 8 . 8}$
\end{tabular}

Note: DOE Operating includes WFDOE \& DOE Direct Operating 
LLNL Staffing \& Education Levels-9/30/97

\begin{tabular}{|c|c|c|c|c|c|c|c|}
\hline Scientists and Engineers & PhD & ENGR & MS & BS & AA & None & TOTAL \\
\hline Physicist (270) & 610 & & 91 & 30 & & 2 & 733 \\
\hline Chemist (242) & 122 & & 32 & 40 & & & 194 \\
\hline Engineer/Patent Eng. $(168,249)$ & 267 & 4 & 403 & 227 & 2 & 19 & 922 \\
\hline Mathematician (285) & 18 & & 2 & 1 & & & 21 \\
\hline Computer Sci./Math Prog. (285) & 50 & 1 & 176 & 197 & 2 & 8 & 434 \\
\hline Biomedical Sci. $(225,277)$ & 18 & & 11 & 15 & & & 44 \\
\hline Biophysicist (235) & 2 & & 4 & & & & 6 \\
\hline Biochemist (221) & 1 & & & & & & 1 \\
\hline Environmental Scientist (230) & 16 & & 25 & 25 & & & 66 \\
\hline Metallurgist (265) & 26 & 1 & 6 & 2 & 1 & & 36 \\
\hline M.D. (Research/Staff) (263) & 6 & & & & & & 6 \\
\hline \multirow[t]{2}{*}{ Political Scientist (295) } & 8 & & 5 & 2 & & & 15 \\
\hline & 1144 & 6 & 755 & 539 & 5 & 29 & 2478 \\
\hline Administrative and Clerical & PhD & ENGR & MS & BS & AA & None & TOTAL \\
\hline Management $(196,197)$ & 15 & & 54 & 34 & 1 & 16 & 120 \\
\hline Professional $(163-165,169,170)$ & 5 & & 21 & 26 & 1 & 16 & 69 \\
\hline Administrative (100-162) & 10 & & 101 & 202 & 75 & 349 & 737 \\
\hline \multirow{2}{*}{ Clerical/Gen'l Serv. (400-462) } & & & 2 & 39 & 58 & 549 & 648 \\
\hline & 30 & & 178 & 301 & 135 & 930 & 1574 \\
\hline Technical and Crafts & PhD & ENGR & MS & BS & AA & None & TOTAL \\
\hline \multicolumn{8}{|l|}{ Security/Fire Dept } \\
\hline$(051,055,650-656)$ & & & 1 & 23 & 39 & 138 & 201 \\
\hline \multicolumn{8}{|l|}{ Technical (302-339, 347-391, } \\
\hline $502-588)$ & 1 & & 28 & 281 & 597 & 826 & 1733 \\
\hline Trades $(722-799,805-990)$ & & & & 14 & 73 & 414 & 501 \\
\hline \multicolumn{8}{|l|}{ Facilities/OJT/Gen. Helper } \\
\hline$(700,701,704,801)$ & & & & & 1 & 4 & 5 \\
\hline & 1 & & 29 & 318 & 710 & 1382 & 2440 \\
\hline & 1175 & 6 & 962 & 1158 & 850 & 2341 & 6492 \\
\hline
\end{tabular}




\section{Appendices}

Engineering Costs by Budget Type FY96-FY97

\begin{tabular}{lrrr} 
& \multicolumn{1}{c}{ FY96 } & FY97 \\
Personnel Charges (OPC) & $\$ 26,111$ & $\$ 21,159$ & $40.8 \%$ \\
G\&A & $\$ 6,664$ & $\$ 5,890$ & $10.4 \%$ \\
Facility Charges (OFC) & $\$ 13,880$ & $\$ 12,921$ & $21.7 \%$ \\
Program Management (PMC) & $\$ 131$ & $\$ 295$ & $0.2 \%$ \\
Recharges & $\$ 11,973$ & $\$ 13,662$ & $18.7 \%$ \\
WFO/WFDOE & $\$ 2,141$ & $\$ 2,404$ & $3.3 \%$ \\
Laboratory Directed R\&D/Weapons Support & $\$ 2,945$ & $\$ 4,781$ & $4.6 \%$ \\
Capital Equipment & $\$ 90$ & $\$ 215$ & $0.1 \%$ \\
& $\$ 63,935$ & $\$ 61,327$ &
\end{tabular}

Note: G\&A does not include Technology Transfer

\section{Engineering 5-Year Costs}

$\begin{array}{lrrrrr} & \text { FY93 } & \text { FY94 } & \text { FY95 } & \text { FY96 } & \text { FY97 } \\ & & & & & \\ \text { Personnel Charges (OPC) } & \$ 37,394 & \$ 30,939 & \$ 30,147 & \$ 26,111 & \$ 21,159 \\ \text { G\&A } & \$ 14,580 & \$ 11,761 & \$ 6,840 & \$ 6,664 & \$ 5,890 \\ \text { Facility Charges (OFC) } & \$ 0 & \$ 0 & \$ 9,554 & \$ 13,880 & \$ 12,921 \\ \text { Program Management (PMC) } & \$ 0 & \$ 0 & \$ 80 & \$ 131 & \$ 295 \\ \text { Recharges } & \$ 6,102 & \$ 14,936 & \$ 10,114 & \$ 11,973 & \$ 13,662 \\ \text { WFO/WFDOE } & \$ 900 & \$ 897 & \$ 1,059 & \$ 2,141 & \$ 2,404 \\ \text { Lab Directed R\&D/ } & & & & \$ 2,945 & \$ 4,781 \\ \quad \text { Weapons Support } & \$ 5,348 & \$ 3,140 & \$ 3,177 & \$ 104 & \$ 215 \\ \text { Capital Equipment } & \$ 1,423 & \$ 1,193 & \$ 482 & \$ 61,327\end{array}$

\section{Engineering Staffing Profile-9/30/97}

\begin{tabular}{lrrrr}
\hline & Total & Career & Term & Other Labor \\
\hline 100 Series-Administrative & 37 & 36 & 1 & 0 \\
200 Series-Engineer & 737 & 645 & 35 & 57 \\
300 Series-Supv./Associate & 364 & 342 & 6 & 16 \\
400 Series-Clerical & 96 & 79 & 10 & 7 \\
500 Series-Technician/Draft & 702 & 633 & 44 & 25 \\
700 Series-Trainee & 8 & 0 & 0 & 8 \\
900 Series-Machinist & 135 & 135 & 0 & 0 \\
TOTAL & $\mathbf{2 , 0 7 9}$ & $\mathbf{1 , 8 7 0}$ & $\mathbf{9 6}$ & $\mathbf{1 1 3}$ \\
\end{tabular}

Note: Other Labor includes Indeterminates and Retirees 
FY97 Manpower Changes (FTEs)

Directorate

Biology \& Biotechnology Research (B\&BR)

Chemistry \& Materials Science (C\&MS)

Computation

Defense \& Nuclear Technologies (D\&NT)

Deputy Director for Science \& Technology (DDS\&T)

Energy

Engineering

Earth \& Environmental Sciences (EE\&S)

Lasers

Nonproliferation, Arms Control \& Int'l Security (NAI)

Physics \& Space Technology (P\&ST)

Plant Operations

Other

TOTAL FTEs
Oct. 96 Sep. 97 Delta \% Change

$\begin{array}{rrrr}12.4 & 12.5 & 0.1 & 0.8 \% \\ 22.7 & 24.3 & 1.6 & 7.0 \% \\ 32 & 40.6 & 8.6 & 26.9 \% \\ 468.5 & 486.7 & 18.2 & 3.9 \% \\ 17.5 & 16.1 & -1.4 & -8.0 \% \\ 105.4 & 111.3 & 5.9 & 5.6 \% \\ 301.5 & 321.2 & 19.7 & 6.5 \% \\ 30.4 & 22.8 & -7.6 & -25.0 \% \\ 617.2 & 600 & -17.2 & -2.8 \% \\ 125.1 & 118.6 & -6.5 & -5.2 \% \\ 115.1 & 100 & -15.1 & -13.1 \% \\ 84.7 & 59.1 & -25.6 & -30.2 \% \\ 13.1 & 17.4 & 4.3 & 32.8 \% \\ \mathbf{1 9 4 5 . 6} & \mathbf{1 9 7 1 . 8} & \mathbf{2 6 . 2} & \mathbf{1 . 3} \%\end{array}$

Engineering Workforce Changes-9/30/97

\begin{tabular}{|c|c|c|c|c|c|c|c|c|c|c|}
\hline & \multicolumn{2}{|c|}{$\begin{array}{c}\text { External } \\
\text { Hires }\end{array}$} & \multicolumn{2}{|c|}{$\begin{array}{c}\text { Transfers } \\
\text { In }\end{array}$} & \multicolumn{2}{|c|}{ Terminations } & \multicolumn{2}{|c|}{ Retired } & \multicolumn{2}{|c|}{$\begin{array}{c}\text { Transfers } \\
\text { Out }\end{array}$} \\
\hline & Career & Non & Career & Non & Career & Non & Career & Non & Career & Non \\
\hline 100 & 0 & 0 & 3 & 0 & 1 & 0 & 1 & 0 & 1 & 0 \\
\hline 200 & 34 & 29 & 16 & 1 & 30 & 14 & 8 & 0 & 6 & 2 \\
\hline 300 & 0 & 6 & 1 & 0 & 13 & 5 & 22 & 0 & 5 & 1 \\
\hline 400 & 0 & 0 & 8 & 5 & 0 & 7 & 1 & 0 & 13 & 7 \\
\hline 500 & 3 & 44 & 12 & 0 & 24 & 8 & 6 & 0 & 11 & 0 \\
\hline 900 & 0 & 0 & 0 & 0 & 2 & 0 & 0 & 0 & 2 & 0 \\
\hline 700 (OJT) & 0 & 6 & 0 & 6 & 0 & 1 & 0 & 0 & 0 & 6 \\
\hline TOTALS & 37 & 85 & 40 & 12 & 70 & 35 & 38 & 0 & 38 & 16 \\
\hline
\end{tabular}

Note: Non-Careers are Indeterminate, Fixed-Term/Temps, Summers, and Retirees 


\section{Engineering Senior Management-9/30/97}

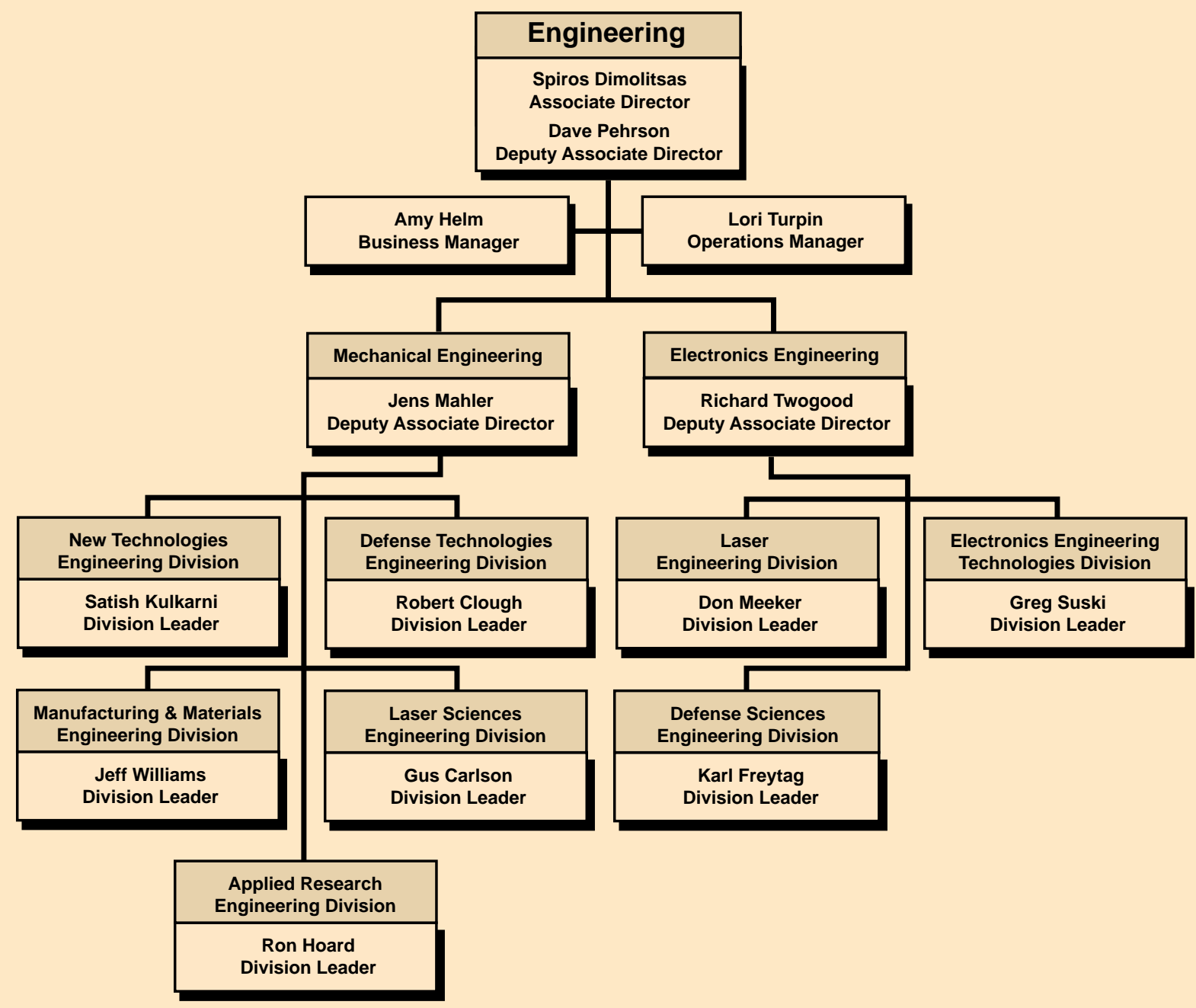

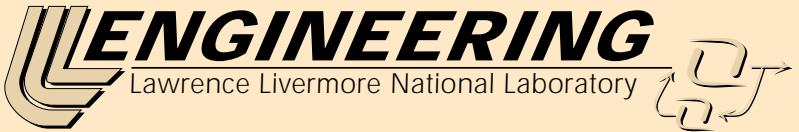




\section{Engineering Facility Changes-9/30/97}

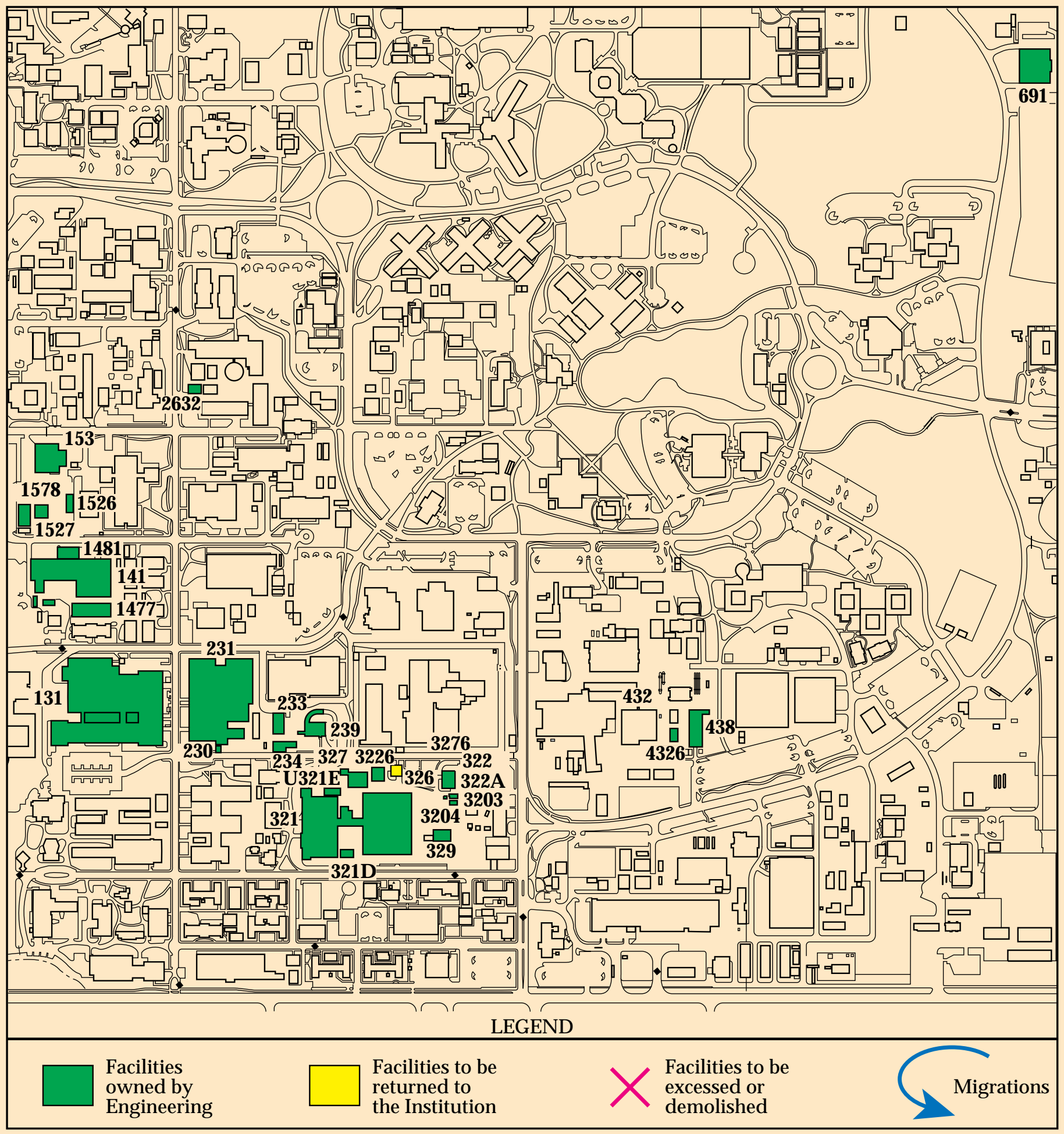




\title{
Writers/Editors
}

\author{
Robert Langland
}

Margaret Sands

\section{Graphic Designer}

Pamela Allen

\section{Production Artists}

\author{
Jeffrey Bonivert \\ Dennis Chan \\ Irene Chan \\ Lucy Dobson \\ Penny Keenan
}

This report has been reproduced directly from the best available copy.

Available to DOE and DOE contractors from the

Office of Scientific and Technical Information

P.O. Box 62, Oak Ridge, TN 37831

Prices available from (615) 576-8401, FTS 626-8401

Available to the public from the
National Technical Information Service
U.S. Department of Commerce 5285 Port Royal Rd.
Springfield, VA 22161

\begin{abstract}
This document was prepared as an account of work sponsored by an agency of the United States Government. Neither the United States Government nor the University of California nor any of their employees makes any warranty, express or implied, or assumes any legal liability or responsibility for the accuracy, completeness, or usefulness of any information, apparatus, product, or process disclosed, or represents that its use would not infringe privately owned rights. Reference herein to any specific commercial products, process, or service by trade name, trademark, manufacturer, or otherwise, does not necessarily constitute or imply its endorsement, recommendation, or favoring by the United States Government or the University of California. The views and opinions of authors expressed herein do not necessarily state or reflect those of the United States Government or the University of California and shall not be used for advertising or product endorsement purposes.
\end{abstract}

Work performed under the auspices of the U.S. Department of Energy by Lawrence Livermore National Laboratory under Contract W-7405-Eng-48. 
Engineering Directorate

Lawrence Livermore National Laboratory

P.O. Box 808, L-151

Livermore, California 94551

http://www.llnl.gov/eng 